17 Sparks RA. Problems with IUCD tails. Br Med f 1977;ii:1351-2.

18 Cohen L, Thomas G. Copper versus the gonococcus in vivo. Br $\mathcal{F}$ Vener Dis $1974 ; 50: 364-6$.

19 Martindale W. In: Wade A, ed. The extra pharmacopoeia. 27th edn. London: The Pharmaceutical Press, 1977:893-6.

${ }^{20}$ Buckingham MS, Sparks RA, Watt PJ, Elstein M. Pelvic infection and intrauterine devices. $\mathrm{Br}$ Med $\mathcal{F} 1976$;ii :942-3.

${ }^{21}$ Bevan AD. Treatment of actinomycosis and blastomycosis with copper salts. F AMA $1905 ; \mathbf{4 5}: 1492-3$.
${ }^{22}$ Luff RD, Gupta PK, Spence MR, Frost JK. Pelvic actinomycosis and the intrauterine contraceptive device. A cytohistomorphologic study. $A m \mathcal{F}$ Clin Pathol 1978;69:581-6.

${ }^{23}$ Gupta PK, Malkani PK, Bhasin K. Cellular response in the uterine cavity after IUD insertion and structural changes in the IUD. Contraception $1971 ; 4: 375-84$.

${ }^{24}$ Johnson AB Jr, Maness RF, Wheeler RG. Calcareous deposits formed on IUDs in human exposures. Contraception 1976;14:507-17.

(Accepted 26 fune 1980)

\title{
Sodium and potassium intake and blood pressure
}

\author{
PETER BURSTYN， DEE HORNALL，CAROL WATCHORN
}

\section{Summary and conclusions}

Sodium and potassium intakes were increased in normotensive volunteers to assess the effects on their blood pressures. An approximately threefold increase in sodium intake for eight days had no effect on the blood pressures of seven volunteers, while a two-stage increase in potassium intake, by about $\mathbf{4 0 \%}$ for eight days and a further $55 \%$ for 14 days, had no effect on the blood pressures of 21 volunteers. Renal electrolyte excretions and the blood pressures of all 28 subjects showed no statistically significant correlations between either sodium or potassium excretion and blood pressure. A weak negative correlation was found between the sodium: potassium ratio and systolic pressure.

The small reductions in sodium intake and increases in potassium intake that might be achieved through propaganda and changes in food processing are unlikely to lower mean blood pressure in Western societies.

\section{Introduction}

Most authors of review articles have condemned the highsodium, low-potassium diets of Western man. ${ }^{1-3}$ Sasaki blames the hypertension of the Japanese on their high sodium intake and suggests that areas in Japan whose populations have less hypertension than average may be protected by their high potassium intakes. ${ }^{4}$ Nevertheless, several authors have failed to find any relation between sodium intake and blood pressure in five different countries, ${ }^{5-10}$ and very recent reviews have tended to agree that the case against sodium has not been completely proved. ${ }^{11-13}$ On the other hand, the antihypertensive effect of potassium has been shown only in children consuming a great deal of sodium ${ }^{14}$ and in rats with salt-induced hypertension. ${ }^{15}$

Raised intakes of sodium may cause high blood pressures in man, ${ }^{1617}$ but this may not be a general response of the whole population. ${ }^{18} 19$ So far the protective effects of potassium have been shown only in cases of salt-induced hypertension. Nevertheless, it has been suggested that small changes in sodium ${ }^{20}$ and potassium intake ${ }^{21}$ may cause changes in the blood pressures of normal individuals. We have observed the effects of increasing the sodium intake and the potassium intake on the blood pressures of two groups of normotensive volunteers.

\footnotetext{
School of Biochemical and Physiological Sciences, University of Southampton, Southampton S09 3TU

PETER BURSTYN, PHD, lecturer in physiology

DEE HORNALL, BSC, final-year science studen

CAROL WATCHORN, BSC, final-year science student
}

\section{Subjects and methods}

Twenty-eight normotensive volunteers took part in the study. Seven subjects (three women, four men aged 20-35 years) increased their sodium intake for eight days. The three women and two of the men took 25 Ciba Slow Sodium tablets $(600 \mathrm{mg}$ or $10 \mathrm{mmol} \mathrm{NaCl}$ each) daily. The two remaining men, whose renal sodium excretion was higher than that of the others, took 30 tablets daily. The experimental period was preceded and followed by eight-day control periods. All urine produced during the 24 days was collected, the volume and time of each micturition noted, and a small sample preserved for analysis. The urine samples were analysed for sodium and potassium using a Corning 435 flame photometer. The results were expressed as mean daily excretions of sodium and potassium for the various periods. Changes in all variables during the experimental period were compared with control values using the paired $t$ test.

Twenty-one subjects (11 women, 10 men aged 20-47 years) increased their potassium intake for 22 days. For eight days the subjects replaced their table salt with a mixture of equal parts of commercial table salt and potassium chloride. This was followed by 22 days during which the 11 women took eight Ciba Slow K tablets ( $600 \mathrm{mg}$ or $8 \mathrm{mmol} \mathrm{KC1}$ ) daily while the 10 men took 10 tablets daily. The experimental periods were preceded by a 14-day control period and followed by a 10-day control period. Urine was collected as above, but only for four 48-hour periods, one towards the end of each control and experimental period. Analysis was carried out as above.

During the study all the subjects had their blood pressure measured two or three times a week. They also refrained from strenuous activity, which might have resulted in a large electrolyte loss in the sweat, during the experiment. All blood pressures were measured using a Hawksley random zero sphygmomanometer, using the fifth Korotkoff sound as the diastolic pressure. The subjects were seated quietly for 10 minutes before the measurements. Each blood pressure measurement was the mean of three cuff inflations. Subjects were asked to clench their fist gently between inflations to reduce the possibility of diastolic pressure distortion through the pooling of venous blood.

\section{Results}

In the first experiment sodium intake was increased sufficiently to raise the renal sodium excretion by $190 \%$ for eight days. This change in sodium intake had no significant effect on either systolic or diastolic blood pressure (table I). While sodium intake was raised there was a slight increase in renal potassium excretion.

In the second experiment the potassium intake was increased in two stages. The first stage increased renal potassium excretion by $40 \%$ for eight days while the second stage caused a further increase of $55 \%$ for 14 days. Although the renal sodium excretion was expected to diminish slightly during the first stage, when table salt was replaced by a mixture of sodium chloride and potassium chloride, this did not occur. Neither change in potassium intake had any effect on either systolic or diastolic blood pressure (table II). There -was a small statistically significant fall in the pulse pressure during both periods of increased potassium intake. 
TABLE I-Effects of dietary sodium supplementation on the blood pressure and renal electrolyte excretion of 7 volunteers. Values are means $\pm S E$

\begin{tabular}{|c|c|c|c|c|}
\hline \multirow{2}{*}{ Period } & \multirow{2}{*}{$\begin{array}{c}\mathrm{Na}^{+} \text {excretion } \\
(\mathrm{mmol} / \text { day })\end{array}$} & \multirow{2}{*}{$\begin{array}{l}\text { K+ excretion } \\
\text { (mmol/day) }\end{array}$} & \multicolumn{2}{|c|}{ Blood pressure $(\mathrm{mm} \mathrm{Hg})$} \\
\hline & & & Systolic & Diastolic \\
\hline Control & \multirow{3}{*}{$\begin{array}{c}142 \cdot 7 \pm 6 \cdot 8 \\
p<0 \cdot 001 \\
414 \cdot 1 \pm 14 \cdot 4 \\
p<0 \cdot 001 \\
157 \cdot 6 \pm 10 \cdot 1\end{array}$} & $66 \cdot 2 \pm 5 \cdot 5$ & $120 \cdot 1 \pm 1 \cdot 8$ & $79 \cdot 4 \pm 1 \cdot 6$ \\
\hline $\mathrm{NaCl}$ supplemen & & $72 \cdot 8 \pm 5 \cdot 1$ & $117 \cdot 2 \pm 2 \cdot 6$ & $76 \cdot 3 \pm 2 \cdot 3$ \\
\hline Control .. & & $65 \cdot 6 \pm 5.9$ & $117 \cdot 7 \pm 1 \cdot 9$ & $77 \cdot 6 \pm 2 \cdot 0$ \\
\hline
\end{tabular}

TABLE II-Effects of substituting mixture of equal parts sodium chloride and potassium chloride for table salt for eight days and of adding "Slow K" for 14 days on blood pressures and renal electrolyte excretions of 21 volunteers. Values are means $\pm S E$

\begin{tabular}{|c|c|c|c|c|c|}
\hline \multirow{2}{*}{ Period } & \multirow{2}{*}{\multicolumn{2}{|c|}{$\begin{array}{c}\mathrm{Na}^{+} \text {excretion } \\
(\mathrm{mmol} / \text { day) }\end{array}$}} & \multirow{2}{*}{$\begin{array}{l}\text { K+ excretion } \\
\text { (mmol/day) }\end{array}$} & \multicolumn{2}{|c|}{ Blood pressure (mm $\mathrm{Hg})$} \\
\hline & & & & Systolic & Diastolic \\
\hline Control .. & . & $171 \cdot 3 \pm 16 \cdot 4$ & $53.4 \pm 4.2$ & $115 \cdot 3 \pm 1 \cdot 6$ & $79.5 \pm 0.8$ \\
\hline $\mathrm{Na}^{+}+\mathrm{K}^{+}$ & .. & $188 \cdot 6 \pm 13 \cdot 9$ & $75.5 \pm 5.8$ & $114 \cdot 7 \pm 1 \cdot 6$ & $80 \cdot 2 \pm 0.8$ \\
\hline Slow $\mathbf{K}^{+} \ldots$ & . & $173 \cdot 3 \pm 12 \cdot 0$ & $\begin{array}{r}p<0.001 \\
117.0 \pm 5.1 \\
p<0.001\end{array}$ & $114 \cdot 8 \pm 1 \cdot 4$ & $80 \cdot 2 \pm 0.9$ \\
\hline Control .. & .. & $160 \cdot 7 \pm 13 \cdot 5$ & $59.0 \pm 3.8$ & $115 \cdot 1 \pm 1 \cdot 2$ & $80.5 \pm 0.8$ \\
\hline
\end{tabular}

Correlation coefficients ( $r$ ) calculated for the mean renal electrolyte excretion values and systolic and diastolic blood pressures of all 28 subjects during their control periods showed no statistically significant interdependence between the arterial pressure and the renal sodium or potassium excretion (table III). Systolic pressure was negatively correlated with the sodium to potassium ratio, although the degree of interdependence $\left(\mathrm{r}^{2}\right)$ was only $15 \%$. Dividing the 28 subjects into groups with different renal sodium and potassium excretions (tables IV and V) showed no significant differences in blood pressure between these groups.

The subjects who increased their sodium intake showed a rapid weight increase of $1.5 \%(p<0.01)$ after the start of the experimental period. This weight was lost promptly after the experimental period. Increasing the potassium intake caused no consistent weight change.

Only six of the 28 individuals had any family history of hypertension. This was too small a sample from which to obtain a correlation coefficient between blood pressure and renal electrolyte excretion. There was no evidence that these six individuals were different from the rest of the subjects in any way.

\section{Discussion}

Our results suggest that increasing the sodium intake of normal individuals to amounts similar to those eaten in Japan ${ }^{4}$ has no effect on blood pressure in the short term. Murray et al showed increases in the blood pressures of their volunteers only when very large quantities of sodium were administered ${ }^{22}$ amounts far greater than those consumed by any human society. The response of the blood pressure to changes in sodium intake appears to be rapid, occurring within seven days in one report ${ }^{18}$ and within three days in another. ${ }^{22}$

The correlation between blood pressure and renal sodium excretion reported here was small and not statistically significant. Pietinen et al showed a good correlation between blood pressure

TABLE III-Correlation coefficients $(r)$. between control values of systolic and diastolic pressures and renal electrolyte excretion from tables $I$ and II

\begin{tabular}{|c|c|c|c|}
\hline & & \multicolumn{2}{|c|}{ Blood pressure } \\
\hline & & Systolic & Diastolic \\
\hline $\begin{array}{l}\text { Sodium excretion } \\
\text { Potassium excretion } \\
\text { Sodium:potassium }\end{array}$ & $\begin{array}{l}\ldots \\
\cdots \\
\cdots\end{array}$ & $\begin{array}{c}-0.252 \\
0.204 \\
-0.390 \\
(p<0.05)\end{array}$ & $\begin{array}{r}0.160 \\
0.252 \\
-0.148\end{array}$ \\
\hline
\end{tabular}

TABLE IV-Comparison between individuals with different renal sodium excretions. Control values for renal electrolyte excretion and blood pressure are given. Values are means $\pm S E$

\begin{tabular}{|c|c|c|c|c|c|}
\hline & \multirow{2}{*}{$\underset{\text { excretion }}{\mathrm{Na}^{+}}$} & \multirow{2}{*}{$\begin{array}{c}\mathbf{K}^{+} \\
\text {excretion } \\
\text { (mmol/day) }\end{array}$} & \multicolumn{2}{|c|}{ Blood pressure $(\mathrm{mm} \mathrm{Hg})$} & \multirow{2}{*}{ Age } \\
\hline & & & Systolic & Diastolic & \\
\hline $\begin{array}{c}\text { High Na } \\
(\mathrm{n}=6)\end{array}$ & $\begin{array}{c}258 \cdot 4 \pm 32 \cdot 5 \\
p<0.01\end{array}$ & $56 \cdot 3 \pm 12 \cdot 1$ & $116 \cdot 2 \pm 3 \cdot 0$ & $81 \cdot 3 \pm 1 \cdot 8$ & $25 \cdot 2 \pm 4 \cdot 4$ \\
\hline$\underset{(n=17)}{\operatorname{Medium}} \mathrm{Na}$ & $\begin{array}{r}150.8 \pm 4.5 \\
p<0.001\end{array}$ & $58 \cdot 5 \pm 4 \cdot 0$ & $116 \cdot 3 \pm 1 \cdot 8$ & $78.5 \pm 0.9$ & $22 \cdot 7 \pm 1 \cdot 1$ \\
\hline$\underset{(n=5)}{\text { Low Na }}$ & $97 \cdot 2 \pm 9 \cdot 8$ & $50 \cdot 7 \pm 6 \cdot 3$ & $120 \cdot 4 \pm 2 \cdot 9$ & $81 \cdot 6 \pm 0.9$ & $24 \cdot 2 \pm 3 \cdot 2$ \\
\hline
\end{tabular}

TABLE $\mathrm{v}-$ Comparisons between individuals with different renal potassium excretions. Control values for renal electrolyte excretion and blood pressure are given. Values are means $+S E$

\begin{tabular}{|c|c|c|c|c|c|}
\hline & \multirow{2}{*}{$\underset{\substack{\text { excretion } \\
\text { (mmol/day) }}}{\mathrm{Na}^{+}}$} & \multirow{2}{*}{$\underset{\text { excretion }}{\mathbf{K}^{+}}$} & \multicolumn{2}{|c|}{ Blood pressure ( $\mathrm{mm} \mathrm{Hg}$ ) } & \multirow{2}{*}{ Age } \\
\hline & & & Systolic & Diastolic & \\
\hline \multirow{3}{*}{$\begin{array}{c}\text { High K+ } \\
(n=8) \\
\text { Medium } \mathbf{K}^{+} \\
(\mathbf{n}=16) \\
\text { Low } \mathbf{K}^{+} \\
(\mathbf{n}=4)\end{array} \quad}$. & $176 \cdot 2 \pm 35.9$ & \multirow{3}{*}{$\begin{array}{c}79.1 \pm 4 \cdot 0 \\
p<0.001 \\
51 \cdot 8 \pm 1.9 \\
p<0.001 \\
29.5 \pm 2.7\end{array}$} & $118 \cdot 6 \pm 2.9$ & $80 \cdot 1 \pm 2 \cdot 1$ & $26 \cdot 6 \pm 3 \cdot 5$ \\
\hline & $156 \cdot 6 \pm 12.8$ & & $116 \cdot 8 \pm 1 \cdot 8$ & $79.5 \pm 0.8$ & $22 \cdot 7 \pm 1 \cdot 2$ \\
\hline & $170 \cdot 8 \pm 18 \cdot 1$ & & $112.0 \pm 1.6$ & $78 \cdot 2 \pm 1 \cdot 0$ & $20.5 \pm 0.5$ \\
\hline
\end{tabular}

and renal sodium excretion but only in those individuals with a family history of hypertension. ${ }^{19}$ Too few of our volunteers had family histories of hypertension for us to confirm this observation. Kawasaki et al, studying a group of hypertensive patients, showed that the blood pressures of some responded well to changes in sodium intake while others were apparently insensitive. ${ }^{18}$ Nevertheless, recent surveys of unselected populations have failed to find any relation between blood pressure and sodium intake. ${ }^{910}$

Increasing the potassium intake in two stages had no effect on the blood pressures of our volunteers. Mickelsen et al achieved an increase in renal potassium excretion similar to that seen in our first stage using the same technique. ${ }^{23}$ They measured blood pressures only twice but thought that there had been no change. Gros et al gave potassium supplements to patients with essential hypertension but failed to decrease their blood pressures. ${ }^{24}$

Before the advent of reliable drug treatment special salt-free diets were used to lower blood pressures in hypertensive patients, ${ }^{25}$ although some contemporary workers reported effects which were too small to be clinically useful. ${ }^{26}$ More recently Parijs et al showed that halving the salt intake of a group of hypertensive patients for several weeks resulted in only small reductions (about $6 \%$ ) in blood pressure. ${ }^{27}$ The suggestion made by Freis that "reduction of salt in the diet to below $2 \mathrm{~g}$ ( $34 \mathrm{mmol})$ per day would result in the prevention of essential hypertension and its disappearance as a major public health problem"' appears optimistic. The blood pressures of the Japanese, ${ }^{28}{ }^{29}$ whose sodium intake is chronically high, are not much higher than those measured in a London survey ${ }^{30}$ or in the USA, ${ }^{29}$ despite the prevalence of hypertension in Japan. ${ }^{1}$ On the other hand, blood pressures are generally high in Finland while the renal sodium excretion is lower than that in Japan. ${ }^{5}$ We consider that genetic ${ }^{18} 19$ and dietary factors ${ }^{31-33}$ have at least as large a part to play in essential hypertension as sodium or potassium. The relatively small reductions in sodium intake and increases in potassium intake that might be achieved through propaganda and changes in food processing are unlikely to lower the mean blood pressure in Western countries. Such manoeuvres may be useful to people who are genetically susceptible to salt-induced hypertension or whose salt intake is unusually high.

\section{References}

${ }^{1}$ Dahl LK. Salt and hypertension. Am $\mathcal{f}$ Clin Nutr 1972 ;25:231-44.

${ }^{2}$ Freis ED. Salt, volume, and the prevention of hypertension. Circulation $1976 ; 53: 589-94$. 
3 Meneely GR, Battarbee HD. High sodium-low potassium environment and hypertension. $A m \mathcal{F}$ Cardiol 1976;38:768-85.

${ }^{4}$ Sasaki N. High blood pressure and the salt intake of the Japanese. $f p n$ Heart 7 1962;3:313-24.

${ }^{5}$ Karvonen MJ, Punsar S. Sodium excretion and blood pressure of West and East Finns. Acta Med Scand 1977;202:501-7.

${ }^{6}$ Malhotra SL. Dietary factors causing hypertension in India. Am $\mathrm{f} \mathrm{Clin}$ Nutr 1970;23:1353-63.

${ }^{7}$ Miall WE. Follow-up study of arterial pressure in the population of a Welsh mining valley. $B r$ Med $71959 ; 2: 1205-10$.

${ }^{8}$ Phear DN. Salt intake and hypertension. Br Med f 1958;ii:1452.

${ }^{9}$ Schlierf G, Arab L, Schellenberg B, et al. Salt and hypertension: data from the "Heidelberg Study." Am F Clin Nutr 1980;33:872-5. survey. Clin Sci Mol Med 1978;55, suppl 4:373-6s.

10 Simpson FO, Waal-Manning HJ, Bolli P, Phelan EL, Spears GF Relationship of blood pressure to sodium excretion in a population survey. Clin Sci Mol Med 1978;55, suppl 4: 373-6s.

11 Anonymous. Hypertension-salt poisoning ? Lancet 1978;i:1136-7.

12 Tobian L. The relationship of salt to hypertension. Am $\mathcal{f}$ Clin Nutr $1979 ; 32: 2739-48$

13 Williams DRR. Salt intake and the pathogenesis of hypertension. Nutrition Bulletin 1980;28:187-93.

14 McQuarrie I, Thompson WH, Anderson JA. Effects of excessive ingestion of sodium and potassium salts on carbohydrate metabolism and blood pressure in diabetic children. $\mathcal{F}$ Nutr 1936;11:77-101.

${ }^{15}$ Meneely GR, Ball COT. Experimental epidemiology of chronic sodium chloride toxicity and the protective effect of potassium chloride. Am 7 Med 1958;25:713-25.

${ }^{16}$ Dahl LK, Love RA. Etiological role of sodium chloride intake in essential hypertension in humans. F $A M A$ 1957;164:397-400.

17 Joosens JV, Willems J, Claessens J, Claes J, Lissens W. Sodium and hypertension. In: Fidanza F, Keys A, Ricci G, et al, eds. Nutrition and cardiovascular diseases. Rome: Morgagni Edizioni Scientifiche, 1971.

18 Kawasaki T, Delea CS, Bartter FC, Smith H. The effect of high-sodium and low-sodium intakes on blood pressure and other related variables in human subjects with idiopathic hypertension. $A m \mathcal{F}$ Med 1978;64: 193-8.

19 Pietinen PI, Wony O, Altschue AM. Electrolyte output, blood pressure and family history of hypertension. Am f Clin Nutr 1979;32:997-1005.
20 Williams LC, Turney JH, Parson V. Dietary fibre and blood pressure. BrMedF 1980;280:181.

${ }^{21}$ Parfrey $\mathrm{P}$, Condon $\mathrm{K}$, Wright $\mathrm{P}$. Dietary fibre and blood pressure. Br Med F 1980; 280:182.

${ }^{22}$ Murray RH, Luft FC, Bloch R, Weyman AE. Blood pressure responses to extremes of sodium intake in normal man. Proc Soc Exp Biol Med $1978 ; 159: 432-6$.

${ }^{23}$ Mickelsen O, Makdani D, Gill JL, Frank RL. Sodium and potassium intakes and excretions of normal men consuming sodium chloride or a 1:1 mixture of sodium and potassium chlorides. Am $\mathfrak{f}$ Clin Nutr $1977 ; 30: 2033-40$.

${ }^{24}$ Gros G, Weller JM, Hoobler SW. Relationship of sodium and potassium intake to blood pressure. Am $\mathcal{F}$ Clin Nutr $1971 ; 24: 605-8$.

$25 \mathrm{Kempner} W$. Treatment of hypertensive vascular disease with rice diets. Am $\mathcal{F}$ Med 1948;4:545-77.

${ }^{26}$ Perera GA, Blood DW. The relationship of sodium chloride to hypertension. $\mathcal{F}$ Clin Invest $1947 ; 26: 1109-18$.

27 Parijs J, Joosens JV, Van der Linden L, Verstreken G, Amery AKPC Moderate sodium restriction and diuretics in the treatment of hypertension. Am Heart $\mathcal{F} 1973 ; 85: 22-34$.

${ }^{28}$ Nutrition Section, Public Sanitation Bureau. The present status of national nourishment-the result of National Nourishment Survey, 1959, 1960, and 1961. Tokyo: Ministry of Health and Welfare.

29 Telcom Health Research Group. Cardiovascular risk factors among Japanese and American telephone executives. Int $\mathcal{f}$ Epidemiol 1977; 6:7-15.

${ }^{30}$ Hamilton M, Pickering GW, Roberts JAF, Sowry GSC. The aetiology of essential hypertension. 1. The arterial pressure in the general population. Clin Sci Mol Med 1954;13:11-37.

31 Armstrong B, Clarke H, Martin C, Ward W, Norman N, Masarei J. Urinary sodium and blood pressure in vegetarians. Am $\mathcal{F}$ Clin Nutr $1979 ; 32: 2472-6$.

32 Burstyn PG, Husbands DF. Fat induced hypertension in rabbits. Effects of dietary fibre on blood pressure and blood lipid concentration. Cardiovasc Res 1980;14:185-91.

33 Wright A, Burstyn PG, Gibney MJ. Dietary fibre and blood pressure. Br Med F 1979;2:1541-3.

(Accepted 4 fuly 1980)

\title{
"Benign" monoclonal IgE gammopathy
}

\author{
H LUDWIG, W VORMITTAG
}

\section{Summary and conclusions}

So far IgE monoclonal paraproteins have been found only in patients with malignant diseases, though there are benign monoclonal paraproteins of other immunoglobulin classes. A patient with osteoporosis first seen in Paris in 1965 was found to have a paraprotein type $\lambda$. In 1977 immunoelectrophoresis identified this as IgE $\lambda$ paraprotein, and immunodiffusion studies showed precipitin bands identical with those in patients with IgE myeloma.

This patient seemed to have a benign monoclonal IgE gammopathy which had existed for 14 years. Though the possibility of transition into multiple myeloma cannot be excluded, this case suggests that a monoclonal expansion of IgE lymphocytes need not produce malignant change.

\section{Introduction}

"Benign" monoclonal paraproteins can be found in about $1 \%$ of the population over 25 years of age. With increasing age the

\footnotetext{
Department of Internal Medicine II, University of Vienna and Ludwig Boltzmann Institute for Gerontology, Vienna, Austria H LUDWIG, MD, senior registrar W VORMITTAG, MD, assistant professor
}

incidence of paraprotein rises to more than $2.5 \%$ in individuals over 70. Thus benign paraproteinaemia of the IgG, IgA, IgM class or of light-chain type is relatively common and only rarely followed by multiple myeloma or Waldenström's macroglobulinaemia. For IgE, however, the immunoglobulin class with normally only trace serum concentrations, no benign monoclonal IgE gammopathy has been reported so far, although 13 cases of IgE myeloma ${ }^{1-4}$ and two patients with lymphoproliferative disorders ${ }^{5} 6$ and IgE paraproteinaemia have been described up to now.

\section{Case report}

A 71-year old woman was referred in 1977 for evaluation of occasional discomfort in her lumbar spine. She had suffered from malnutrition and anaemia from 1939 to 1946 . In 1963 she had complained of pain in the thoracolumbar region. Calcium injections were given, but no radiographs taken until December 1965, when severe pain and almost complete immobilisation led to her admission to hospital in Paris, where osteoporosis with collapse of several vertebrae was found. Haemoglobin was $8.2 \mathrm{~g} / \mathrm{dl}$, leucocyte count $6.2 \times 10^{9} / 1$ with $35 \%$ lymphocytes (half atypical). The erythrocyte sedimentation rate was $40 \mathrm{~mm}$ in $1 \mathrm{~h}$, while serum calcium, phosphate, and serum protein concentrations were normal. Serum electrophoresis disclosed a minimal spike in the gamma region. Proteinuria was $250 \mathrm{mg} / 24 \mathrm{~h}$ with no Bence Jones protein. Calcium excretion was $60 \mathrm{mg} / 24 \mathrm{~h}$ on an unrestricted diet and $150 \mathrm{mg} / 24 \mathrm{~h}$ after intravenous calcium. In January 1966 immunoelectrophoresis (Professor M Seligmann) showed a paraprotein type $\lambda$, which was not detected in unconcen- 